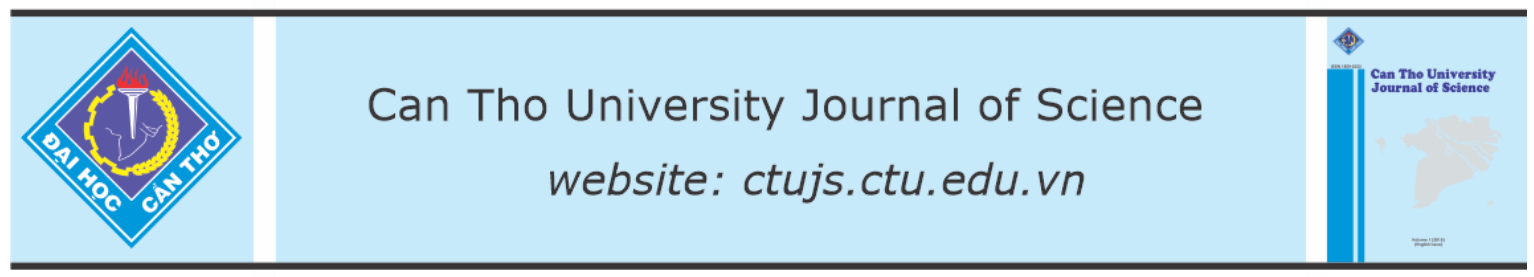

DOI: $10.22144 /$ ctu.jen.2021.045

\title{
Value chain and competitiveness of OCOP standardized clown knife fish products in Hau Giang province
}

Nguyen Thuy Trang* and Vo Hong Tu

College of Rural Development, Can Tho University, Viet Nam

*Correspondence: Nguyen Thuy Trang (email: nttrang@ctu.edu.vn)

\section{Article info.}

Received 16 May 2021

Revised 22 Jun 2021

Accepted 19 Jul 2021

\section{Keywords}

Competitiveness, clown knife fish, OCOP, value chain

\begin{abstract}
The study was conducted to analyze the competitiveness of OCOP standardized clown knife fish products in Hau Giang province. The data were collected from 73 observations involved in the clown knife fish value chain. The research results show that most farmers culture knife fish intensively and the feed cost shares the highest proportion of the total production cost. Processed products from knife fish are mainly boneless fish and fish balls. The OCOP knife fish value chain operated through four main distribution channels and included actors: fish farmers, traders, processors, and retailers. The farmers normally sell fresh knife fish to middleman, accounting for $80.15 \%$. The processing factories create and share the highest proportion of added value. The distribution channel that farmers are linked directly with processors create higher added value than others. The study also analyzed the Porter's five forces of the knife industry. The study found that there are many potential risks in the farming process, high competitive pressures from substitute products, and limited negotiation ability of both farmers and processors.
\end{abstract}

\section{INTRODUCTION}

The fisheries sector of Viet Nam has achieved a rapid and stable development, making an important contribution to the economic growth, poverty reduction, improving the rural living standards and contributing to the agricultural restructuring (Directorate of Fisheries, 2019). Aquaculture plays an important role in ensuring food security and bringing the country a great amount of export values. In 2020, the total fisheries and aquaculture production reached about 8.4 million tons, of which the fishery industry shares 3.85 million tons and the aquaculture shares 4.56 million tons. The export turnover was estimated at 8.6 billion USD (Directorate of Fisheries, 2020).

The Mekong Delta is one of the core agricultural regions and has favourable conditions for aquaculture development, with the total farming area of about 800 thousand hectares (Directorate of Fisheries, 2019). Within 236 freshwater fish species found, more than 50 fish species are considered to be of high economic value. In which, clown knife fish or Chitala chitala has a great potential in terms of economic values and adaptation to natural conditions in the Mekong Delta. In Viet Nam in general and in the Mekong Delta in particular, there are two main species of knife fish: Notopterus notopterus and Chitala chitala (La, 2012). The knife fish are widely distributed in provinces such as Kien Giang, Soc Trang, Dong Thap, Vinh Long, Can Tho, Hau Giang... Chitala chitala is one of the popular farming species because the fish has large size, fast growth rate, delicious meat and can be raised with high density, which brings high revenue for farmers (La, 2012). 
Hau Giang is an agricultural province with about 54,000 hectares of water surface that are suitable for aquaculture, the total aquaculture output in 2019 in the province was 62,250 tons (Statistical Office of Hau Giang province, 2020). Currently, regarding to the fish species, the province has many different species such as snakehead fish, perch, catfish, and knife fish (Chitala chitala), in which Chitala chitala has been expanding in terms of the farming area in many localities such as Phung Hiep, Chau Thanh districts and Nga Bay city. The total production of knife fish in Hau Giang province reached over 6,000 tons, the farming area increased from 48 hectares in 2018 to 85 hectares in 2019 (People's Committee of Hau Giang province, 2020). Knife fish is considered as a specialty of Hau Giang province and recognized widely by consumers. "Ca That Lat Hau Giang" trademark was registered and granted a trademark registration certificate by Intellectual Property Office of Viet Nam - Ministry of Science and Technology in 2014. In particular, 17 products from knife fish have been standardized and certified as OCOP $^{1}$ (One Commune One Product). Within 17 OCOP knife fish products, 15 products were categorized "four stars" (New Rural Coordination Office of Hau Giang, 2020).

Although the aquaculture sector in general and the knife fish in particular in Hau Giang have achieved a remarkable development, farmers have been also encountering some difficulties and challenges, such as (1) low quality of fish breeds, (2) lack of farming techniques, (3) the limited and inefficient linkages between actors in the value chain. Thus, the study on the competitiveness of the OCOP standardized knife fish industry in Hau Giang province was conducted to analyse the competitiveness, finding the proper and efficient channels for upgrading the knife fish value chain to contribute to proposing solutions to help producers reduce production costs and increase added value, which contribute to improving the competitive advantages of Hau Giang knife fish industry in the market.

\section{LITERATURE REVIEW}

\subsection{Overview of studies related to value chain analysis}

Value chain refers to a business model that describes the full range of activities needed to create and supply a product or service to end-consumers

${ }^{1}$ OCOP stands for One Commune One Product. This movement has been implemented in Quang Ninh since 2013 as a pilot or demonstration. This movement was
(Gereffi \& Korzenniewicz, 1994; Kaplinsky \& Morris, 2001). A value chain comprises steps that involve bringing a product from conception to distribution such as procuring raw materials, processing functions, and marketing activities. Many studies related to value chain have been conducted in the world, especially for agriculture based countries. The aims of the value chain research are mainly related to studying the interaction among actors, the degree of interaction, the factors affecting the degree of interaction, and regional economic integration. Many previous studies show that a sustainable value chain requires actual cooperation and trust between actors (Hirschman, 1958; Corbett et al., 1999; Barratt \& Oliveira, 2001; Callioni \& Billington, 2001).

The value chain of agricultural products has also been conducted by many domestic researchers to determine the scale, production characteristics, processing, distribution channels, product quality, price formation process, distribution, analysis of added value, advantages and disadvantages of actors in the chain in order to redistribute benefits to the target actors in the value chain of agricultural products such as rice, pangasius, avocados, garlic, sugarcane, grape, vegetables etc. The previous studies indicate that farming households share a high proportion of added value as compared to others actors, but if we consider the duration of cultivation (from land preparation to distribution), the farmers share the lowest proportion of added value, indicating that their income is also the lowest (Vo, 2016; Duong, 2014; Hoang, 2014; Nguyen, 2012a\&b; Tran, 2011; Vo, 2009; Vo \& Nguyen, 2011).

Value chains have been used by economic researchers for various research purposes over the past decade. The three main research streams in the value chain literature are:(i) the filière approach, (ii) the conceptual framework elaborated by Porter and (iii) the global approach proposed by Kaplinsky.

Initially, the 'filière' approach was used to analyse the agricultural system of developing countries. The approach mainly served as a tool to study the ways in which the agricultural production systems were organised in the context of developing countries. In this context, the filière framework paid special attention to how local production systems were

officially implemented since 2018 at all provinces based on the decision 490/QĐ-TTg promulgated on 07/05/2018. 
linked to processing industry, trade, export and final consumption.

The concept of value chain first mentioned by Porter (1985) is the process of making and maintaining a life cycle of a product from: production design, procurement of inputs, production, logistics, marketing, sales, promotion services. However, Porter's value chain is limited to the level of one firm. Subsequently, Kaplinsky \& Morris (2001); Gereffi \& Korzenniewicz (1994), introduced a global approach. According to Kaplinsky (2000), Kaplinsky \& Morris (2001), a value chain refers to the range of activities required to transform a product (or a service) from conception, through production stages, distribution to the end consumer and dispose after use.

Based on these approaches, many organizations have applied in practice and developed analytical frameworks such as Food and Agriculture Organization (FAO) or German Technical Cooperation (GTZ). In 2006, FAO developed a centralized framework for value chain analysis with two main contents: Financial analysis and economic analysis. In 2007, GTZ introduced a value chain approach called "Valuelinks". Combined with GTZ's ValueLinks approach (2007), DFID - UK
Department for International Development introduced a practical value chain analysis handbook titled "Making Value Chains Work Better for the Poor: A Toolbook for Practitioners of Value Chain Analysis" (Making Markets Work for the Poor - M4P, 2008).

\subsection{The concept of OCOP}

According to Decision 490/QĐ-TTG dated on 07/05/2019, OCOP stands for One Commune One Product. This movement aims at developing the rural economy based on indigenous strengths in terms of natural resources, human capital. This movement is one of the national important programs that contribute to implementing New Rural Program $^{2}$. The main focuses of the OCOP movement are to develop agricultural, nonagricultural products and services that have comparative advantages in each locality.

As OVOP (One Village One Product) movement in Japan, the OCOP movement in Viet Nam also contains three main principles: Act locally, think globally, Self-Reliance and Creativity and Human Resource Development. According to Decision No. 1048/QĐ-TTg, the three basic principles of OCOP movement in Viet Nam are presented as below:

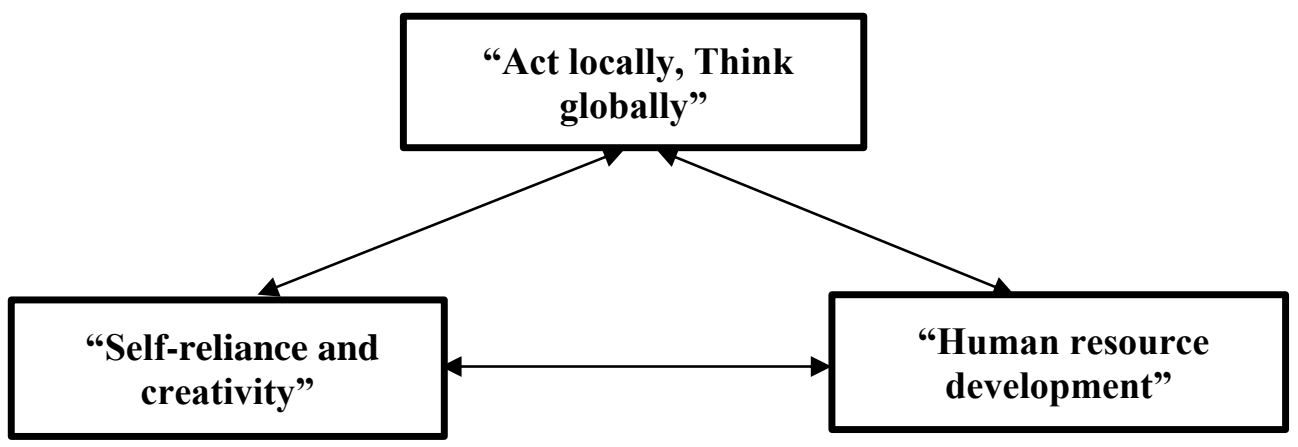

Figure 1. Three basic principles of OCOP movement in Viet Nam

Source: Decision 1048/QĐ-TTg

\subsection{Porter's five force model}

Porter's Five Force model is a useful and effective tool to understand the position of a product in the market and at the same time it provides additional information about the potential competitors and market power. According to Porter (1979), the

${ }^{2}$ New Rural Program was deployed since 2011 based on the decision 8000/QĐ-TG. This program aims at building new rural areas with gradually modern socio-economic infrastructure; rational economic structure and forms of production organization, linking agricultural sector with competition in the market in any industry is determined by five competitive forces: (1) competitive rivalry; (2) supplier power; (3) buyer power; (4) threat of substitution and (5) threat of new entry. The five force model is illustrated in Figure 2.

rapid development of processing industry and services; democratic, stable rural society, rich in national cultural identity; environmental protection; security, etc. 


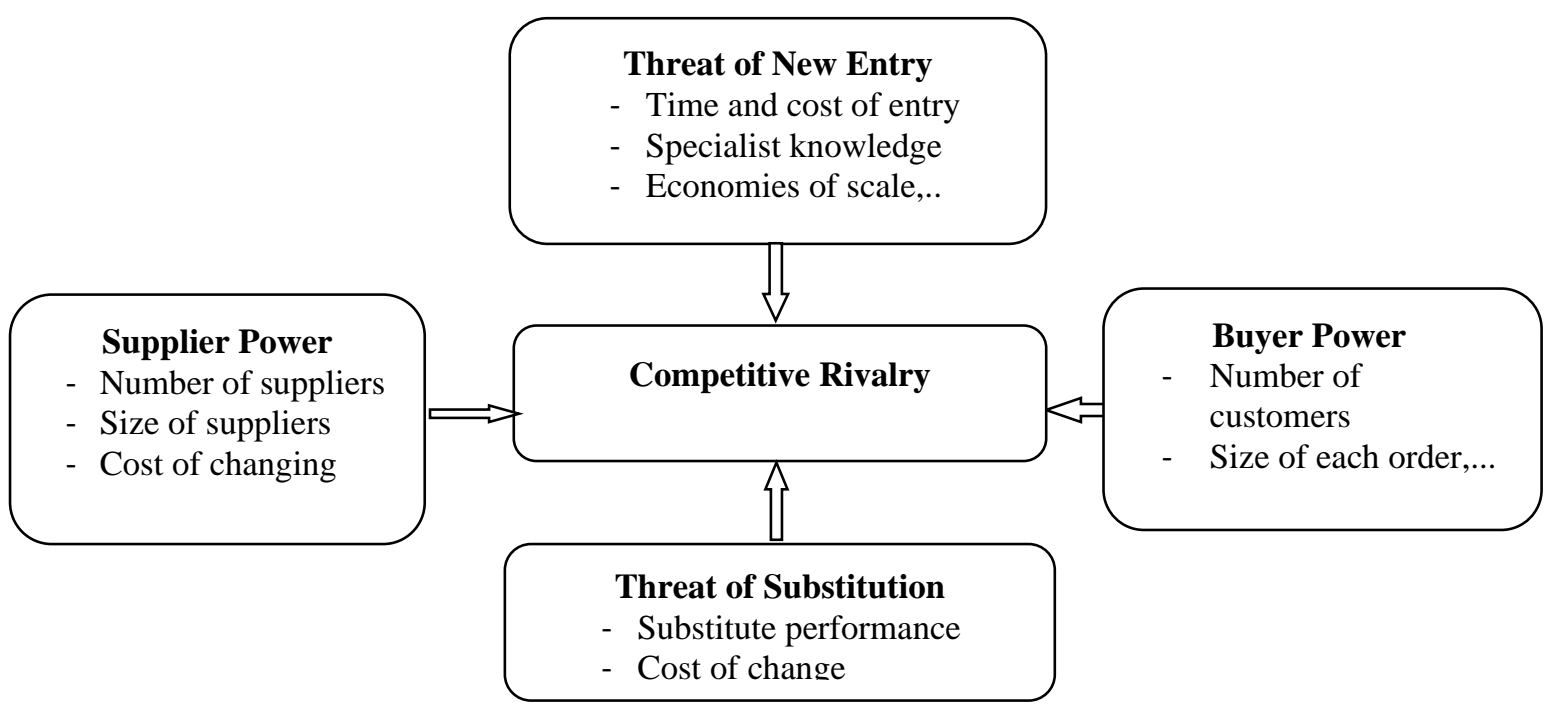

Figure 2. Porter's five forces

(Source: Porter, 1979)

\subsection{Conceptual framework}

In this current study, Porter's five forces were employed to investigate the strengths, weaknesses, opportunities and threats for the whole value chain (all actors) of OCOP standardized knife fish industry in Hau Giang province. For simplicity, the five force model for each actor in the value chain is integrated or pooled into one comprehensive analysis. With this approach or conceptual framework, we aim at providing the comprehensive picture of OCOP standardized knife fish industry for policy makers in Hau Giang province to propose some interventions or upgrading strategies. Basically, the conceptual framework of this current study is presented as below:

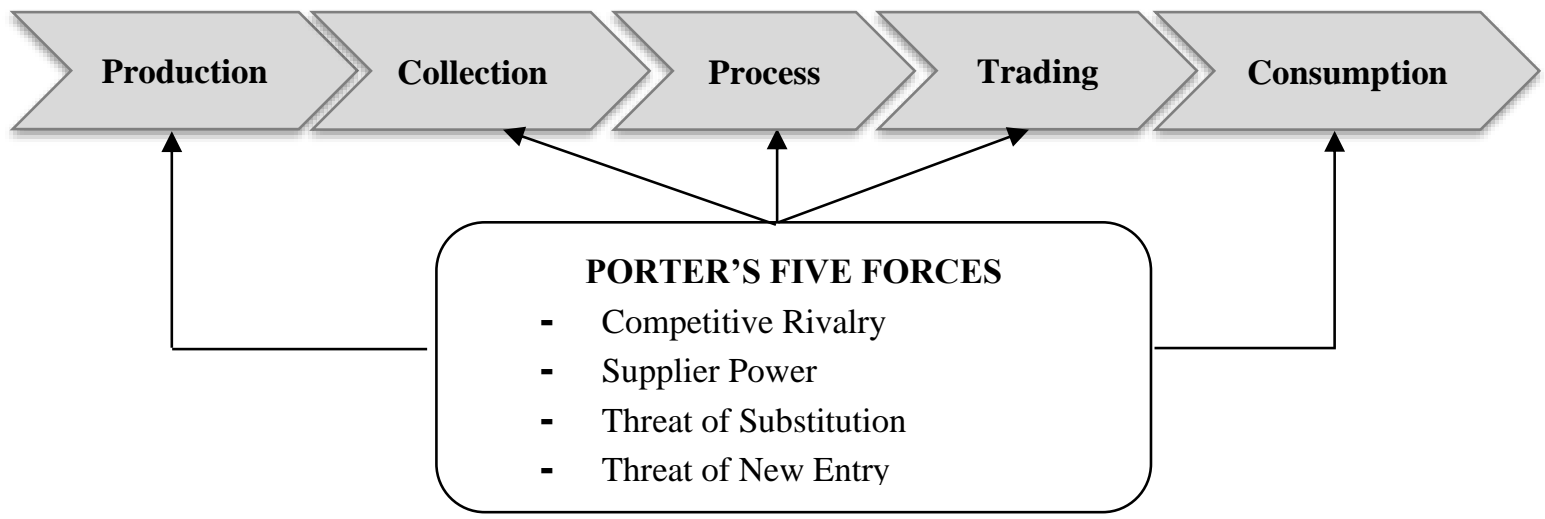

Figure 3. Conceptual framework of the current study

\section{METHODOLOGY}

\subsection{Data collection}

Hau Giang province reserves 86 hectares for knife fish farming, which is concentrated mainly in the districts of Phung Hiep, Chau Thanh, and Nga Bay city (People's Committee of Hau Giang province, 2020). Phung Hiep district is the largest producer of knife fish with approximately 40 ha. Therefore,
Phung Hiep district was selected as the study area. We interviewed 73 observations of four actors in the value chain. For the knife fish farmers, we selected and interviewed farmers based on the list provided by extension workers at five communes and one town, including Thanh Hoa, Hoa My, Phuong Binh, Tan Binh, Hoa An communes and Cay Duong town. The knife fish middleman was selected based on the recommendation of knife fish farmers. For knife fish 
processing factories, we conducted interviews with three processors (Ky Nhu, Tan Hau Giang and Tan Phat) that have knife fish products certified as OCOP products. Details of the sample size for each actor are described in Table 1.

Besides, KIP (key informant panel) and FGD (focus group discussion) with farmers, processors, consumers and local authorities were conducted to capture the overall picture of five forces of the OCOP standardized knife fish products in Hau Giang.

Table 1. Sample size of the study

\begin{tabular}{lr}
\hline Actors & Sample size \\
\hline Knife fish households & 60 \\
Middleman & 5 \\
Processing factory & 3 \\
Supermarket/retailer & 5 \\
\hline Total & 73 \\
\hline
\end{tabular}

\subsection{Data analysis}

Two main methods for data analysis and synthesis: value chain analysis and Porter's five forces were conducted. A value chain analysis was carried through 3 steps: (1) value chain mapping; (2) quantification and detailed description of value chains; (3) economic analysis of value chain (GTZ, 2007).

Chain mapping: The goal of this tool is to draw a picture of the entire product value chain and describe the picture in terms of: (1) chain function (stages in the chain); (2) chain actors; (3) chain market channel and; (4) organizations or units that support the chain.

Economic analysis: The objective of this tool is to analyze the financial efficiency of each actor in the OCOP standardized knife fish value chain. In order to ensure a consistent calculation between all stages in the chain, when analysing the chain economic performance, it is necessary to convert and unify the same product form for all stages in the chain. In this study, we used fish balls as the base for conducting the economic analysis. For conducting the economic analysis, the study employed the following formulas

$$
\begin{array}{r}
\text { Added value }=(\text { Selling price } \times \text { Quantity }) \\
- \text { Intermediate cost } \\
\text { Net added value } \\
=\text { Added value } \\
- \text { Added cost } \\
\text { Total cost }=\text { Added Cost } \\
+ \text { Intermediary Cost }
\end{array}
$$

\section{Regarding to Porter's five force model}

The study employed this model to identify the advantages and disadvantages of the OCOP standardized knife fish industry in Hau Giang province based on five competitive forces (1) Competitive Rivalry; (2) Supplier Power; (3) Buyer Power; (4) Threat of Substitution and (5) Threat of New Entry.

\section{RESULTS AND DISCUSSION}

\subsection{Value chain analysis of OCOP standardized knife fish in Hau Giang province}

The value chain of OCOP knife fish products in Hau Giang province is operated through six main functions: input, production, collection, processing, trading and consumption. In general, farmers raise fish through two main forms: specialized farming $(88.33 \%)$ and intercropping (11.67\%) with an average farming density of 18.35 fish heads $/ \mathrm{m}^{2}$. The average farm size in the study sites is 2.06 ha per household. We also found that most of the fish farmers do not participate in the cooperatives and do not participate in technical training courses. The value chain of knife fish industry in Hau Giang province operated through four main channels. After the fresh knife fish is sold to processing factories from traders or farmers, the fresh fish are processed into many different products such as: fish balls, boneless whole fish, seasoned knife fish. As we mentioned, in order to conduct the economic analysis for all actors in the value chain, fish ball of knife fish is used a base to calculate added values. In general, in order to produce one $\mathrm{kg}$ of knife fish ball, it requires $2.2 \mathrm{~kg}$ of fresh knife fish. We also found that on the average, $01 \mathrm{~kg}$ of fresh knife fish can produce $0.6 \mathrm{~kg}$ of processed knife fish products (including all types of products such as fish ball, boneless whole fish, seasoned knife fish, etc.).

The value chain diagram of knife fish in Hau Giang province includes the following market channels:

Channel 1: Farmer $\rightarrow$ Middleman $\rightarrow$ Processing factory $\rightarrow$ Supermarkets $\rightarrow$ Consumers

Based on the survey, it was found that Channel 1 accounts for the biggest market share of knife fish products. Basically, farmers sell $82.15 \%$ of the knife fish to middleman. Then, the middlemen sell $82.15 \%$ of the knife fish to the processing factories. In addition, the processing factories also purchased $17.85 \%$ of knife fish from farmers in and outside agricultural cooperatives. The factories processed 
fresh fish into many fish products and distributed $38.30 \%$ of the fish products to supermarkets. Finally, the supermarkets sell the products directly to end-consumers.

\section{Channel 2: Farmer $\rightarrow$ Middleman $\rightarrow$ Processing factory $\rightarrow$ Retailer $\rightarrow$ Consumers}

After being harvested, most of the fish is sold to middleman, and then the middlemen sell all to processors. After processing, the factories sell $39.50 \%$ of fish products to retailers. Finally, the retailers sell the processed products directly to endconsumers.

\section{Channel 3: Farmers $\rightarrow$ Processing factory $\rightarrow$ Supermarket $\rightarrow$ Consumers}

In this channel, farmers in and outside agricultural cooperatives sell $17.85 \%$ of fresh knife fish to processing factories. Then, the factories processed knife fish into many types of products and distributed $38.3 \%$ of all processed products (procurement from both middleman and farmers) to supermarkets, then the products were sold to endusers.

\section{Channel 4: Farmers $\rightarrow$ Processing factory $\rightarrow$} Retailer $\rightarrow$ Consumers

The study found that the knife fish farmers sell $17.85 \%$ of the total harvested fish directly to the processing factories. Along with $82.15 \%$ of procurement from middlemen, the processing factories sell $61.7 \%$ of all fish products to retailers. Recently, thanks to the market promotion supports from local authorities for OCOP products, the OCOP knife fish products in Hau Giang province from three factories (Ky Nhu, Tan Hau Giang and Tan Phat) are distributed to many provinces, such as Ho Chi Minh city, Ha Noi, and Phu Quoc city.

The detailed diagram of the OCOP knife fish value chain in Hau Giang province is illustrated in Figure 4 below:
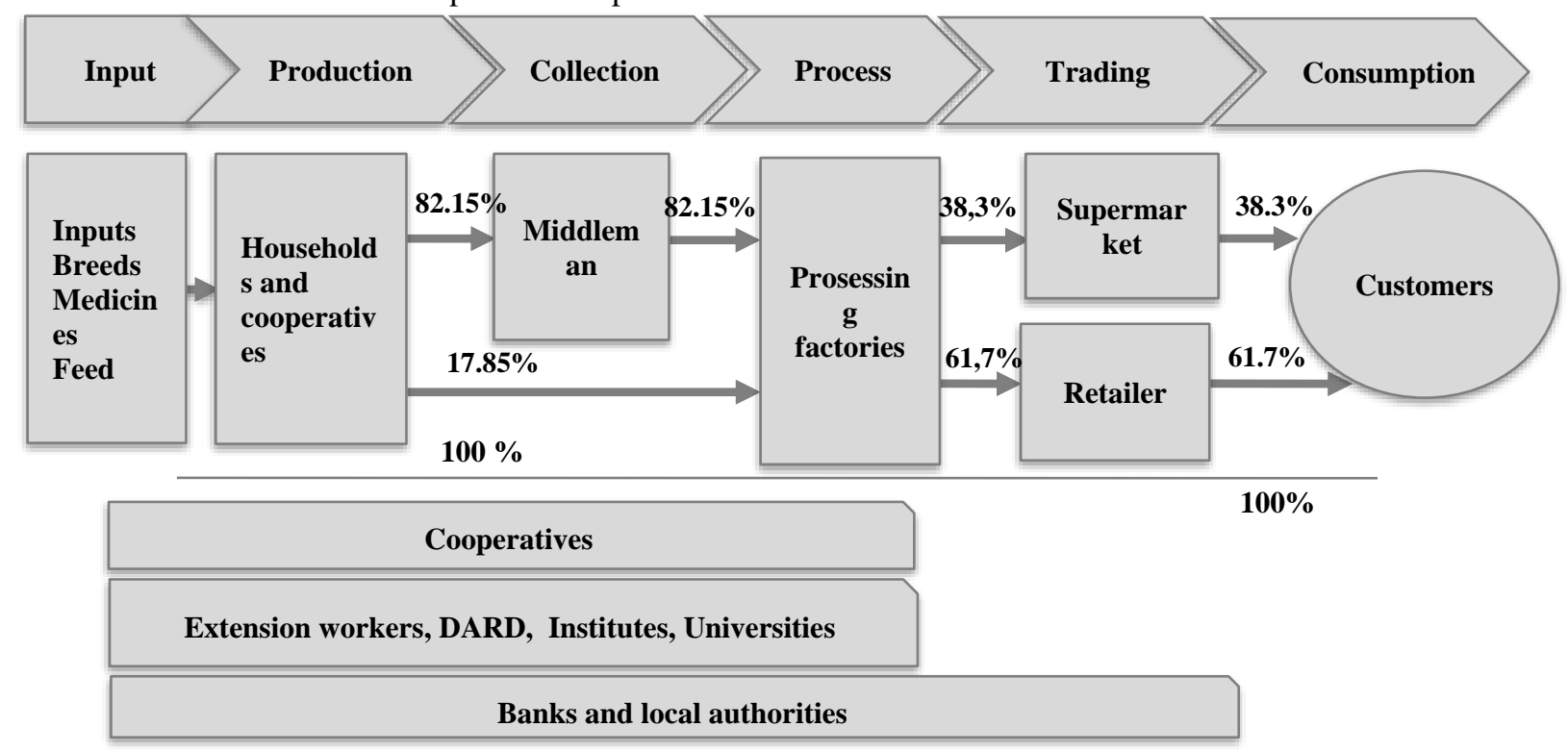

$100 \%$

Figure 4. Value chain diagram of OCOP knife fish in Hau Giang province

Source: Data from survey in 2020, $n=73$

\subsubsection{Cost structure of knife fish production}

The study found that the production cost of knife fish varies greatly among farmers. Within the total cost, feed shares the highest proportion $(80.47 \%)$, followed by breed cost $(8.87 \%)$. In general, it costs about $27,850 \mathrm{VND}$ to produce $1 \mathrm{~kg}$ of fresh fish. 
Table 2. Production cost and added value of farmers

Unit: 1,000 VND/kg

\begin{tabular}{lrr}
\hline Indicators & Cost & \% \\
\hline Selling price (1) & $\mathbf{5 9 . 3 4}$ & - \\
Intermediate cost (2) & $\mathbf{2 5 . 3 5}$ & 91.02 \\
Feed costs & 22.41 & 80.47 \\
Breed cost & 2.47 & 8.87 \\
Depreciation cost & 0.37 & 1.3 \\
Medicine costs & 0.07 & 0.25 \\
Lime costs & 0.03 & 0.11 \\
Value added (3=1-2) & $\mathbf{3 3 . 9 9}$ & - \\
Added cost (4) & $\mathbf{2 . 5}$ & 8.98 \\
Other costs (electricity, fuel, etc.) & 1.11 & 4 \\
Labor costs & 1.03 & 3.7 \\
Pond maintenance costs & 0.36 & 1.3 \\
Total cost $(\mathbf{5}=\mathbf{2 + 4 )}$ & $\mathbf{2 7 . 8 5}$ & $\mathbf{1 0 0}$ \\
Net value added (1-5) & $\mathbf{3 1 . 4 9}$ & - \\
\hline
\end{tabular}

Source: Data from knife fish household survey in 2020, $n=60$

\subsubsection{Added values of actors by market channels}

As we discussed in the previous section, there are 4 market channels for the knife fish value chain. Thus, we conduct the economic analysis in terms of added values for these all 4 market channels. Based on the in-depth interviews with the three processing factories that have OCOP knife fish products, the conversion rate from fresh fish to fish ball is 2.2, which means that $2.2 \mathrm{~kg}$ of fresh fish can produce 1 $\mathrm{kg}$ of fish ball. Based on this conversion ratio, we conduct the economic analysis for actors and market channels (Table 3 ).

In conclusion, the economic analysis of 4 distribution channels in the value chain of OCOP knife fish products in Hau Giang province show that the processing factories share the highest proportion of added value, followed by supermarkets, retailers and then fish farmers. The farmers sell their harvested fish through two main channels: middleman and processing factories. In the distribution channels 3 and 4 where the farmers sell their fish directly to the processing factories, the fish farmers receive higher added value as compared to the other channels. This difference can be explained that the selling prices the farmers sell their fish to the processors is $64,200 \mathrm{VND} / \mathrm{kg}$, which is about $5,000 \mathrm{VND} / \mathrm{kg}$ higher than the price the farmers sell their fish to middleman.

Table 3. Distribution of added values among actors by market channels

Unit: $1,000 \mathrm{VND} / \mathrm{kg}$

\begin{tabular}{|c|c|c|c|c|c|c|}
\hline Items & Household & $\begin{array}{r}\begin{array}{r}\text { Middle } \\
\text { man }\end{array} \\
\end{array}$ & $\begin{array}{r}\text { Processing } \\
\text { factory } \\
\end{array}$ & Retailer & Supermarket & Total \\
\hline \multicolumn{7}{|c|}{ Channel 1: Households $\rightarrow$ Middleman $\rightarrow$ Processing factory $\rightarrow$ supermarket $\rightarrow$ consumers } \\
\hline Price & 59.20 & 69.20 & 190.00 & & 240.00 & \\
\hline Intermediate cost & 25.35 & 59.20 & 69.20 & & 190.00 & \\
\hline Value added & 33.85 & 10.00 & 120.8 & & $\mathbf{5 0 . 0 0}$ & 214.65 \\
\hline Added cost & 2.50 & 7.00 & 66.33 & & 7.00 & \\
\hline Net value added & 31.35 & 3.00 & $\mathbf{5 4 . 4 7}$ & & 43.00 & 131.82 \\
\hline$\%$ Added cost & 15.77 & 4.66 & 55.90 & & 23.29 & 100.00 \\
\hline$\%$ Net value added & 23.78 & 2.28 & 41.32 & & 32.62 & 100.00 \\
\hline \multicolumn{7}{|c|}{ Channel 2: Households $\rightarrow$ Middleman $\rightarrow$ Processing factory $\rightarrow$ Consumers } \\
\hline Price & 59.20 & 69.20 & 190.00 & 220.00 & & \\
\hline Intermediate cost & 25.35 & 59.20 & 69.20 & 190.00 & & \\
\hline Value added & 33.85 & 10.00 & 120.80 & 30.00 & & 194.65 \\
\hline Added cost & 2.50 & 7.00 & 66.33 & 5.00 & & \\
\hline Net value added & 31.35 & 3.00 & $\mathbf{5 4 . 4 7}$ & 25.00 & & 113.82 \\
\hline$\%$ Added cost & 17.39 & 5.14 & 62.06 & 15.41 & & 100.00 \\
\hline$\%$ Net value added & 27.54 & 2.64 & 47.86 & 21.96 & & 100.00 \\
\hline \multicolumn{7}{|c|}{ Channel 3: Households $\rightarrow$ Processing factory $\rightarrow$ Supermarket $\rightarrow$ Consumers } \\
\hline Price & 64.20 & & 190.00 & & 240.00 & \\
\hline Intermediate cost & 25.35 & & 64.20 & & 190.00 & \\
\hline Value added & 38.85 & & 125.80 & & 50.00 & 214.65 \\
\hline Added cost & 2.50 & & 66.33 & & 7.00 & \\
\hline Net value added & 36.35 & & $\mathbf{5 9 . 4 7}$ & & 43.00 & 138.82 \\
\hline$\%$ Added cost & 18.09 & & 58.61 & & 23.29 & 100.00 \\
\hline$\%$ Net value added & 26.18 & & 42.84 & & 30.98 & 100.00 \\
\hline
\end{tabular}




\begin{tabular}{|c|c|c|c|c|c|c|}
\hline Items & Household & $\begin{array}{r}\text { Middle } \\
\text { man }\end{array}$ & $\begin{array}{r}\text { Processing } \\
\text { factory }\end{array}$ & Retailer & Supermarket & Total \\
\hline \multicolumn{7}{|c|}{ Channel 4: Households $\rightarrow$ Processing factory $\rightarrow$ Retailer $\rightarrow$ Consumers } \\
\hline Price & 64.20 & & 190.00 & 220.00 & & \\
\hline Intermediate cost & 25.35 & & 64.20 & 190.00 & & \\
\hline Value added & 38.85 & & 125.8 & 30.00 & & 194.65 \\
\hline Added cost & 2.50 & & 66.33 & 5.00 & & \\
\hline Net value added & 36.35 & & $\mathbf{5 9 . 4 7}$ & 25.00 & & 120.82 \\
\hline$\%$ Added cost & 19.96 & & 64.63 & 15.41 & & 100.00 \\
\hline$\%$ Net value added & 30.09 & & 49.22 & 20.69 & & 100.00 \\
\hline
\end{tabular}

Source: Author's calculation from the data survey in 2020, $n=73$

In Table 3, it was found that the processing factories also prefer to buy fresh fish from farmers than the middlemen because the selling price from farmers is only $64,200 \mathrm{VND} / \mathrm{kg}$ while it is $69,200 \mathrm{VND} / \mathrm{kg}$ from the middlemen, a difference of $5,000 \mathrm{VND} / \mathrm{kg}$. However, the limitation for the linkage between farmers and processing companies is that most farmers raise and sell fish harvests individually. Thus, it is difficult for the processors procure raw materials. For this point, it is necessary for farmers to join into cooperatives and sell the harvests collectively.

\subsection{Analysis of Porter's five force model}

The study also applied Porter's five force model to capture the advantages and disadvantages of the knife fish industry. The detailed analysis of the five forces is presented in Figure 4.

\section{Threat of New Entry}

1. Modern processing technologies become affordable and easy to access $=>$ new competitors join the market

2. Supports from OCOP national program for developing new products $=>$ more competitors

\section{Supplier Power}

1. Feed prices vary greatly, and fish farmers cannot negotiate

2. Feed quality is not good and from uncertified sources

3. Breeds are low quality and the survial rate is also low

4. Some farmers join the cooparative to buy and sell fish to the processors.

\section{Competitive Rivalry}

1. Other provinces in the Mekong Delta also raise knife fish with large scale such as Dong Thap, An Giang

2. Many knife fish processing factories, of which there are three factories having OCOP knife fish products in Hau Giang 3. Packaging and labelling is not nice looking

4. Some labels are not well designed

5. Knife fish is a speciality of Hau Giang with the cerified trademark of "Ca That Lat Hau Giang"

\section{Buyer Power}

1. The bargaining power of fish farmers is low, usually decided by traders and processors.

2. Farmers and consumers do not understand OCOP standards

3. Many promotion fairs are organized for OCOP products

\section{Threat of Substitution}

1. There are many substituted products such as snakehead fish balls, shrimp balls, pangasius fish balls and other kinds of meat with competitive prices.

2. High competition with other aquatic products

\section{Figure 5. Porter's Five force model of the OCOP knife fish industry}

Source: KIP and FGD with farmers, processors, consumers and local authorities. 
The research results show that the production of knife fish industry is under high pressure of competition and potential competitive pressure. In addition, the knife fish industry is also under high competitive pressure from substitute products and from the buyers' market power. Therefore, in order to sustainably develop the knife fish industry in Hau Giang province, it is necessary to use its advantages in terms of natural conditions, production experiences, and take advantage of supports from local authorities to limit and overcome possible risks. In addition, it is necessary to improve production capacity, the negotiation ability of farmers and organize more promotion fairs.

\subsection{Chain upgrade vision and strategy}

\subsubsection{Vision}

Increase income for actors in the value chain, especially farmers who raise knife fish and processing factories who have OCOP products and expand the markets to increase added value.

\subsubsection{Chain upgrading strategy}

In order to contribute to increased income for actors, the proposed strategy is to reduce costs, to employ innovations in production and processing technology and to increase competitiveness.

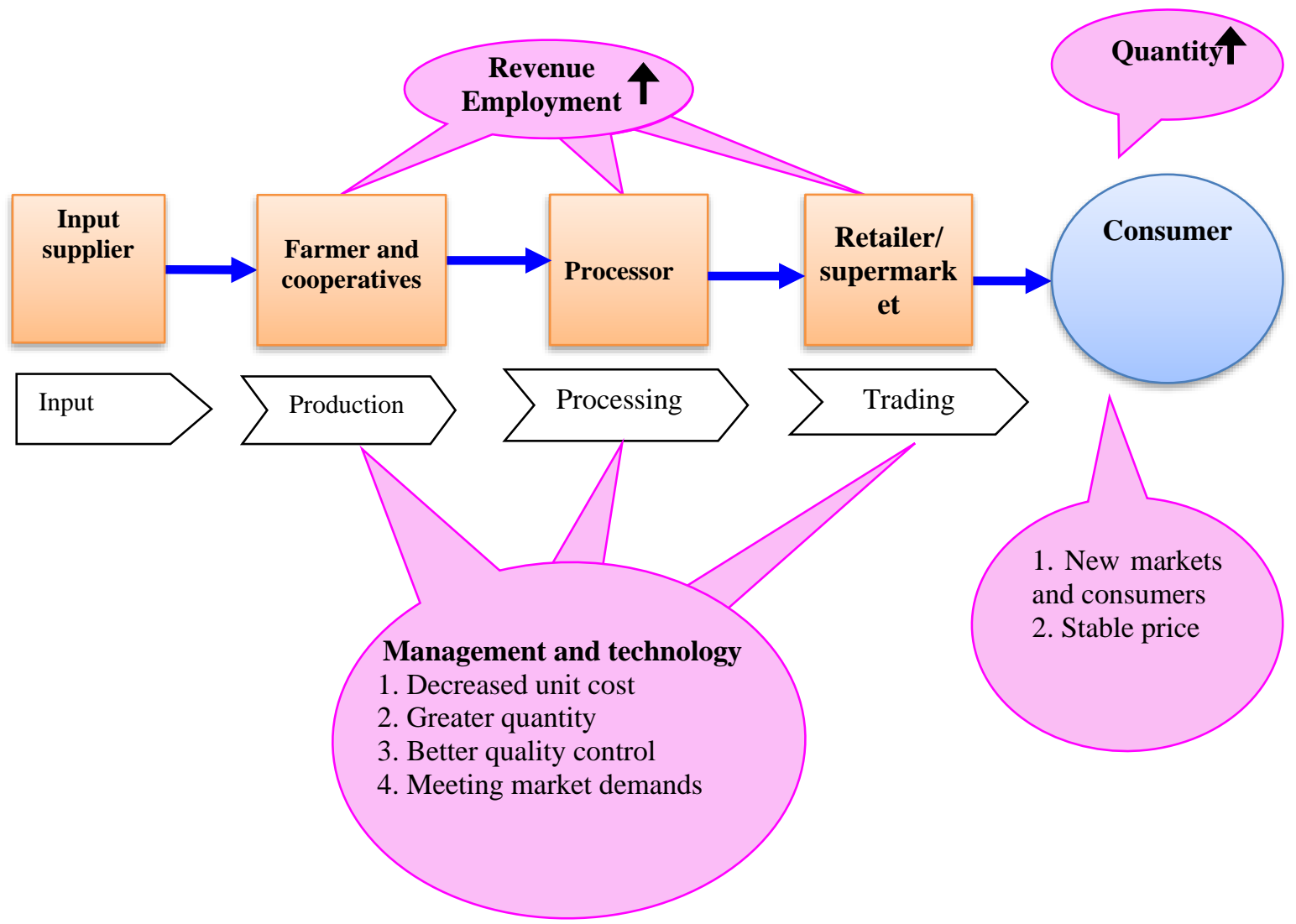

Figure 6. Upgrading strategy diagram of OCOP knife fish value chain

Source: Authors, 2021

\subsubsection{Solutions proposed}

Based on vision, strategy, the proposed solutions are as follows:

(1) For fish farmers: they need to attend more training courses on how to raise fish to reduce production costs, particular feed costs and how to feed the fish according to recommendations in order to contribute to improving fish quality and quantity; reducing production cost. Encouraging farmers to join into cooperatives to produce enough quantity and distribute collectively and directly to processors instead of middlemen.

(2) Strengthening the linkages between actors to shorten distribution channels or eliminate the actors in the value chain. The study found that if farmers 
link with processors, the added value is higher than channels that farmers sell fish through middleman.

(3) Processors need to ensure or improve food hygiene and safety in the processing to meet the fastidious markets and to expand the market. Besides, the processors continue to upgrade their packaging system and redesign their labelling to include OCOP trademark and quality standards.

(4) Local authorities continue to support OCOP knife fish factories to improve the management capacity, particular quality standard management as well to expand the market via promotion fairs.

\section{CONCLUSION}

The research results show that the total production cost for $1 \mathrm{~kg}$ of fresh knife fish is about 27.85 thousand VND. The OCOP knife fish products were distributed through four main channels. Of which, the channels 3 and 4 bring the highest added value

\section{REFERENCES}

Barratt, M., \& Oliveira, A. (2001). Supply Chain Collaboration: Exploring the Early Initiatives - Part One. Supply Chain Practice, 3(4), 34-47.

Callioni, G., \& Billington, C. (2001). Supply chain management-effective collaboration. OR/MS Today October. http://www. lionhrtpub. com/orms.

Corbett, C. J., Blackburn, J. D., \& Van Wassenhove, L. N. (1999). Partnerships to improve supply chains. MIT Sloan Management Review, 40(4), 71-82.

Directorate of Fisheries. (2020). The total export value of agricultural, forestry and fishery products in 2020. Ministry of Agriculture and Rural Development.

Duong, N. T. (2014). Solutions to improve the efficiency of the value chain of Cat mango industry in Dong Thap province. Final report of Department of Science and Technology of Dong Thap province.

Gereffi, G. (1994). The organization of buyer-driven global commodity chains: How US retailers shape overseas production networks. In Gereffi, G. \& Korzeniewicz, M. (Eds), Commodity chains and global capitalism (95-122). Praeger, Connecticut London.

GTZ. (2007). Valuelinks manual. The methodology of value chain promotion. Eschborn, Germany.

Hellin, J., \& Meijer, M. (2006). Guidelines for value chain analysis. Food and Agriculture Organization of the United Nationsm, Rome, Italy.

Hirschman, A. O. (1958). The strategy of economic development (No. 04; HD82, H5.).

Hoang, V. V. (2014). Diversifying markets for consumption of Ben Tre green-skinned pomelo value to farmers. Basically, the processing factories share the highest proportion of added value in the chain, followed by supermarkets, retailers and then the farmers. It was found that about $80.15 \%$ of fish harvests are sold to middleman. The distribution channel that farmers are linked directly with processors creates higher added value than others. This result suggests that farmers need to join agricultural cooperatives. In other words, the fish farmers need to establish a vertical and horizontal linkage to produce enough quantity and distribute collectively the harvests to the fish processors. The Porter's five forces model also shows that the OCOP knife fish products are well known and recognised by consumers in the Mekong Delta and Hau Giang has registered and protected the trademark " $\mathrm{Ca}$ That Lat Hau Giang". However, it was also found that the knife fish industry of Hau Giang is under high competitive pressures from substitute products and threats of new competitors.

chain. Development and Integration Journal, 16(26), 83-91.

Kaplinsky, R. (2000). Globalisation and unequalisation: What can be learned from value chain analysis?. Journal of Development Studies, 37(2), 117-146. https://doi.org/10.1080/713600071

Kaplinsky, R., \& Morris, M. (2000). A handbook for value chain research (Vol. 113). Brighton: University of Sussex, Institute of Development Studies.

La, A. N. (2012). Study some biological characteristiscs of knife fish (Chitala chitala). Scientific Journal of Can Tho University, 21b, 62-67.

Making Markets Work for the Poor (2008). Making Value Chains Work Better for the Poor: A Toolbook for Practitioners of Value Chain Analysis. Agricultural Development International: Phnom Penh, Cambodia.

New Rural Coordination Office of Hau Giang. (2020). Summary of 46 OCOP certified products in Hau Giang in 2020. People's Committee of Hau Giang province.

Nguyen, P. S. (2012a). Situation of the pangasius value chain in the Mekong Delta. Journal of Agriculture and Rural Development, 21, 51-57.

Nguyen, P. S. (2012b). Value chain analysis of apple, garlic and grape products in Binh Thuan province. Department of Science and Technology of Binh Thuan province.

People's Committee of Hau Giang province. (2020). A draft project on Sustainable agricultural development, adaptation to climate change in Hau Giang province for 2021 - 2025, orientation to 2030. People's Committee of Hau Giang province. 
Porter, M. E. (1979). The structure within industries and companies' performance. The review of economics and statistics, 214-227. https://doi.org/10.2307/1924589

Porter, M. E. (1985). Competitive advantage. Free Press, New York, 33-61.

Statistical Office of Hau Giang province. (2020). Statistical year book of Hau Giang. Statistical Publishing House.

Tran, T. K. (2011). Research report on Ben Tre coconut value chain analysis. DBRP Ben Tre.
Vo, T. T. L. \& Nguyen, P. S. (2011). Part 1: Analysis of the rice value chain of the Mekong Delta. Can Tho University Journal of Science, 96-108.

Vo, T. T. L. (2009). Distribution of value added in the shrimp value chain in the Mekong Delta. Journal of Agriculture and Rural Development, 134, 3-8.

Vo, T. T. L. (2016). Assessment of agri-product value chains in the Mekong Delta: Problems and Solutions. Can Tho University Journal of Science, 2, 100-111. https://doi.org/10.22144/ctu.jen.2016.001 